\title{
PENERAPAN METODE REGRESI KUANTIL BAYESIAN PADA PEMODELAN LAMA RAWAT INAP PASIEN COVID-19
}

\author{
ANNISA RAHMADIAH, FERRA YANUAR, DODI DEVIANTO \\ Program Studi S2 Matematika, \\ FMIPA Universitas Andalas, Padang, Indonesia \\ email : annisarahmadiah4@gmail.com,ferrayanuar@sci.unand.ac.id,ddevianto@sci.unand.ac.id
}

\begin{abstract}
Abstrak. Penelitian ini bertujuan untuk mengetahui faktor-faktor yang mempengaruhi lama rawat inap pasien COVID-19. Dalam hal ini variabel tak bebas yang digunakan adalah data lama rawat pasien COVID-19 dengan variabel bebasnya adalah Usia, Jenis Kelamin, Diagnosa Pasien COVID-19, dan Komorbid. Data lama rawat pasien COVID-19 tidak memenuhi asumsi kenormalan sehingga diatasi dengan pendekatan pendugaan parameter menggunakan metode regresi kuantil Bayesian. Adapun pada metode ini pendugaan parameter diestimasi dengan mengasumsikan bahwa error data berdistribusi Asymmetric Laplace, yang kemudian dibentuk sebagai fungsi likelihood-nya. Pendekatan Bayesian pada regresi kuantil menggunakan MCMC dengan algoritma Gibbs sampling untuk menghasilkan mean posterior. Indikator ketepatan model diperoleh dari perhitungan nilai pseudo $R^{2}$ tertinggi. Penelitian ini diperoleh kuantil 0,75 sebagai kuantil terbaik dengan variabel Komorbid sebagai variabel yang berpengaruh signifikan dalam mempengaruhi lama rawat inap pasien COVID-19.
\end{abstract}

Kata Kunci: COVID-19, Regresi Kuantil, Bayesian

\section{Pendahuluan}

Analisis regresi memodelkan hubungan antara variabel tak bebas dengan satu atau lebih variabel bebas yang dinyatakan dalam suatu model regresi. Model regresi diperoleh dengan melakukan estimasi terhadap parameter modelnya. Metode klasik yang dapat digunakan dalam mengestimasi parameter regresi adalah metode kuadrat terkecil (MKT). Metode MKT akan efisien jika telah memenuhi beberapa asumsi yang dibutuhkan agar memperoleh penduga yang bersifat Best Linear Unbiased Estimator (BLUE) [6]. Namun jika terdapat salah satu asumsi tersebut tidak terpenuhi, maka metode MKT tidak efisien digunakan. Untuk mengatasi kelemahan tersebut, salah satu metode yang dapat digunakan adalah metode regresi kuantil. Metode regresi kuantil menggunakan pendekatan pendugaan parameter dengan membagi data menjadi kuantil-kuantil, kemudian menduga fungsi kuantil bersyarat

${ }^{*}$ penulis korespondensi 
pada suatu distribusi data tertentu dan meminimumkan sisaan mutlak berbobot yang tidak simetris tersebut.

Metode regresi kuantil menggunakan pendekatan Bayesian dalam mengestimasi parameter modelnya untuk menghasilkan nilai dugaan yang lebih baik dan lebih hampir mendekati nilai sebenarnya. Hal ini karena metode Bayes memberikan informasi tambahan mengenai distribusi awal mengenai parameter yang dinyatakan dalam bentuk distribusi prior. Metode Bayes menggabungkan distribusi prior dengan informasi dari data sampel yang dinyatakan dalam bentuk fungsi likelihood. Penggabungan tersebut menghasilkan distribusi posterior [16]. Untuk memperoleh distribusi posterior pada metode Bayes maka dilakukan dengan bantuan pendekatan $M C M C$ dengan proses algoritma Gibbs sampling karena efektif digunakan dan mampu mengatasi integrasi analitik yang kompleks [11]. Mean posterior dan variansi posterior yang dihasilkan dari proses pendekatan $M C M C$ digunakan sebagai nilai estimasi parameter pada regresi kuantil Bayesian [12].

Di penghujung tahun 2019, dunia digemparkan dengan munculnya wabah penyakit virus jenis baru yaitu Coronavirus disease 2019 (COVID-19) yang pertama kali dideteksi berasal dari kota Wuhan, China dan kemudian kini telah menyebar ke seluruh dunia termasuk Sumatera Barat, Indonesia [21]. Pasien yang terserang virus COVID-19 akan mengalami gejala yang berbeda tergantung kondisi tiap pasien. Bagi pasien dengan gejala sedang hingga berat, membutuhkan perawatan di rumah sakit hingga dapat dinyatakan pulih dari COVID-19 [17]. Lama rawat inap pasien COVID-19 akan berbeda tiap individunya karena disebabkan oleh berbagai faktor. Untuk mengetahui faktor apa saja yang mempengaruhi lama rawat inap pasien COVID-19 maka dilakukan pemodelan matematika dengan mengestimasi parameter modelnya.

Pada penelitian ini, penulis menggunakan metode regresi kuantil Bayesian dalam mengkontruksi model lama rawat inap pasien COVID-19. Hal ini dikarenakan data lama rawat inap pasien COVID-19 tidak memenuhi uji asumsi kenormalan sehingga diatasi menggunakan metode regresi kuantil Bayesian.

\section{Landasan Teori}

\subsection{Metode Regresi Kuantil}

Regresi kuantil mengembangkan teknik statistika yang digunakan untuk mengembangkan hubungan antara variabel tak bebas dengan variabel bebas. Kuantil membagi sekelompok data menjadi beberapa bagian, setelah data diurutkan dari yang paling kecil ke yang paling besar. Misalkan $Q_{\theta}\left(y_{i} \mid x_{i}\right)$ dinotasikan sebagai fungsi regresi kuantil ke- $\theta$ dari $y_{i}$ bersyarat $x_{i}$ dengan $0<\theta<1$. Fungsi regresi kuantil dapat dinyatakan dalam bentuk $Q_{\theta}\left(y_{i} \mid x_{i}\right)=x_{i}^{\prime} \boldsymbol{\beta}_{\boldsymbol{\theta}}$, untuk $i=1,2, \ldots, n$ dan $\boldsymbol{\beta}_{\boldsymbol{\theta}}$ adalah vektor dari parameter model yang akan diestimasi. Model linier persamaan regresi kuantil dapat diformulasikan dalam bentuk sebagai berikut: [8]

$$
y_{i}=x_{i}^{\prime} \boldsymbol{\beta}_{\boldsymbol{\theta}}+\varepsilon_{i} .
$$

Estimasi dari pada regresi kuantil ke- $\theta$ dapat diperoleh dengan meminimumkan 
loss function yang didefinisikan sebagai berikut: [19]

$$
\sum_{i=1}^{n} \rho_{\theta}\left(y_{i}-x_{i}^{\prime} \boldsymbol{\beta}\right)
$$

dimana $\rho_{\theta}(u)=u(\theta-I(u<0))$ adalah loss function [20], dan $I($.$) adalah fungsi$ indikator.

\subsection{Metode Bayesian}

Pada pendugaan parameter menggunakan metode Bayesian, perlu diketahui bentuk distribusi awal dari parameter yang disebut dengan distribusi prior. Metode Bayesian menggabungkan distribusi prior dari parameter dengan informasi dari data sampel yang dinyatakan dalam bentuk fungsi likelihood. Hasil penggabungan tersebut menghasilkan distribusi baru, yaitu distribusi posterior yang digunakan untuk menduga parameter pada metode Bayesian.

\section{(1) Fungsi Likelihood}

Definisi 2.1. [3] Fungsi kepekatan peluang bersama dari $n$ peubah acak; $X_{1}, X_{2}, \cdots, \quad X_{n}$ yang dihitung pada $x_{1}, x_{2}, \cdots, x_{n}$ dapat dinotasikan dengan $f\left(x_{1}, x_{2}, \cdots, x_{n} ; \beta\right)$ yang merupakan fungsi likelihood. Untuk nilai $x_{1}, x_{2}, \cdots, x_{n}$ tertentu, fungsi likelihoodnya merupakan fungsi dari parameter $\beta$ yang dapat dinotasikan dengan $L(\beta)$. Jika $X_{1}, X_{2}, \cdots, X_{n}$ merupakan contoh acak yang saling bebas dari $f(\boldsymbol{x} ; \beta)$ maka:

$$
\begin{aligned}
L(\beta) & =f\left(x_{1} ; \beta\right) f\left(x_{2} ; \beta\right) \cdots f\left(x_{n} ; \beta\right) \\
& =\prod_{i=1}^{n} f\left(x_{i}, \beta\right)
\end{aligned}
$$

\section{(2) Distribusi Prior}

Distribusi prior merupakan distribusi awal yang memberikan informasi mengenai parameter yang akan diduga. Dalam pendugaan suatu nilai parameter, maka distribusi prior dapat dipilih secara subjektif oleh peneliti. Distribusi prior terbagi atas dua, yaitu:[4]

(a) Berkaitan dengan bentuk distribusi hasil identifikasi pola datanya yang diperoleh dari fungsi likelihood, yaitu:

1. Distribusi prior konjugat. Distribusi prior ini mengacu pada pemilihan prior pada suatu model terutama dalam pola fungsi likelihoodnya.

2. Distribusi prior non konjugat. Pemberian prior pada model tidak mengindahkan pola pembentuk fungsi likelihoodnya.

(b) Berkaitan dengan informasi terdahulu terkait dengan penentuan masingmasing parameter pada pola distribusi priornya, yaitu:

1. Distribusi prior informatif. Distribusi prior ini mengacu pada pemberian parameter dari distribusi prior yang telah dipilih, baik distribusi prior konjugat maupun prior non-konjugat. 
2. Distribusi prior non-informatif. Distribusi prior ini tidak berdasarkan pada data yang ada atau distribusi prior yang tidak mengandung informasi mengenai parameter.

\section{(3) Distribusi Posterior}

Definisi 2.2. [3] Fungsi kepekatan peluang bersyarat dari $\beta$ jika diketahui pengamatan sampel $x=\left(x_{1}, x_{2}, \cdots, x_{n}\right)$ disebut fungsi kepekatan peluang posterior yang didefinisikan sebagai berikut:

$$
f(\beta \mid \boldsymbol{x})=\frac{L(\beta) f(\beta)}{\int_{-\infty}^{\infty} L(\beta) f(\beta) d \beta}
$$

\subsection{Metode Regresi Kuantil Bayesian}

Metode regresi kuantil Bayesian merupakan gabungan antara metode regresi kuantil dengan pendekatan Bayesian. Dalam [20] menemukan bahwa meminimumkan loss function regresi kuantil yang diformulasikan pada Persamaan (2.2) ekuivalen dengan memaksimalkan fungsi likelihood yang dibentuk dari data yang diasumsikan berdistribusi Asymmetric Laplace Distribution (ALD). Asumsikan bahwa peubah acak $\varepsilon \sim A L D$ dengan bentuk fungsi kepekatan peluangnya sebagai berikut: [2] [20]

$$
f_{\theta}(\varepsilon)=\theta(1-\theta) \exp \left(-\rho_{\theta}(\varepsilon)\right) .
$$

dimana $0<\theta<1$ dan $\rho_{\theta}(\varepsilon)$ adalah loss function dengan $\varepsilon$ sebagai error dari pendugaan dan $I(\varepsilon)$ merupakan fungsi indikator.

Diberikan pengamatan $\boldsymbol{y}=\left(y_{1}, y_{2}, \ldots, y_{n}\right)$. Untuk menggabungkan metode regresi kuantil ke dalam pendekatan Bayesian dalam melakukan dugaan parameter $\beta$, maka digunakan $A L D$ sebagai fungsi likelihood yang dinyatakan sebagai berikut:

$$
L(\boldsymbol{\beta})=\theta^{n}(1-\theta)^{n} \exp \left\{-\sum_{i=1}^{n} \rho_{\theta}\left(y_{i}-x_{i}{ }^{\prime} \boldsymbol{\beta}\right)\right\} .
$$

Distribusi posterior dari $\beta$ diperoleh dengan mengalikan fungsi likelihood pada Persamaan (2.6) dengan distribusi posterior $\beta$ yakni $p(\boldsymbol{\beta})$ sehingga distribusi posterior diperoleh sebagai berikut:

$$
\begin{aligned}
f(\boldsymbol{\beta} \mid \boldsymbol{y}) & \propto L(\boldsymbol{\beta}) p(\boldsymbol{\beta}) . \\
& =\theta^{n}(1-\theta)^{n} \exp \left\{-\sum_{i=1}^{n} \rho_{\theta}\left(y_{i}-x_{i}^{\prime} \boldsymbol{\beta}\right)\right\} p(\boldsymbol{\beta}) .
\end{aligned}
$$

Dalam menentukan distribusi posterior untuk dugaan parameter $\boldsymbol{\beta}_{\boldsymbol{\theta}}$ pada penggunaan $A L D$ sebagai fungsi likelihood untuk data secara langsung sulit diselesaikan secara analitik [11]. Untuk mengatasi kesulitan tersebut, maka digunakan pendekatan numerik yakni dengan bantuan algoritma $M C M C$ (Markov Chain Monte Carlo yang tidak hanya efektif digunakan tetapi juga mampu mengatasi integrasi analitik yang kompleks [20].

Untuk menguji ketepatan model yang dihasilkan dari metode regresi kuantil Bayesian dapat diperoleh dengan menghitung nilai pseudo $R^{2}$. Rumus untuk menghitung nilai pseudo $R^{2}$ dapat diformulasikan sebagai berikut: [5] 


$$
\text { pseudoR }{ }^{2}=1-\frac{R A S W_{\theta}}{T A S W_{\theta}}
$$

$R A S W_{\theta}$ adalah jumlah sisaan mutlak berbobot antara variabel tak bebas dan distribusi kuantil bersyarat yang diduga dalam model yang lebih kompleks, dan $T A S W_{\theta}$ adalah jumlah total mutlak berbobot antara variabel ta bebas dengan dugaan kuantil dalam model yang sederhana. Nilai pseudo $R^{2}$ berkisar antara 0 dan 1, dan semakin mendekati 1 maka model yang dihasilkan akan sempurna [5].

\subsection{Faktor-Faktor yang Mempengaruhi Lama Rawat Inap Pasien COVID-19}

Lama rawat inap dari pasien yang terinfeksi COVID-19 akan bervariasi tiap masingmasing individu. Hal ini tergantung gejala serta kondisi yang dialami pasien tersebut. Bagi pasien yang mengalami gejala sedang hingga berat, maka membutuhkan perawatan di rumah sakit hingga dinyatakan pulih dari COVID-19. Dengan demikian, perlu dikaji faktor-faktor pendukung yang erat hubungannya dengan lama rawat inap pasien COVID-19. Berikut adalah faktor pendukung yang mempengaruhi lama rawat pasien COVID-19 berdasarkan kajian terdahulu: [9] [13] [14]

(1) Usia

Secara umum, pasien dengan usia lanjut akan rentan terserang virus dikarenakan erat kaitannya dengan adanya proses degeneratif anatomi, imunitas yang menurun. Selain itu, lansia memiliki masalah jangka pnjang dalam kesehatan sehingga berisiko tinggi terinfeksi COVID-19 dikarenakan sistem kekebalan tubuhnya melemah seiring pertambahan usia [1].

(2) Jenis Kelamin

Jenis kelamin laki-laki lebih rentan terinfeksi COVID-19 dibandingkan perempuan dikarenakan laki-laki memiliki gaya hidup yang cenderung tidak sehat. Selain itu, laki-laki memiliki kebiasaan merokok serta perempuan lebih peduli terhadap kondisi lingkungan dan kesehatan [14].

(3) Diagnosa Pasien COVID-19

Berdasarkan [10] diagnosa pasien COVID-19 dibedakan berdasarkan kategori berikut: Orang Dalam Pantauan (ODP) yaitu orang yang memiliki gejala seperti gangguan pernpasan dan harus menjalani isolasi selama lebih kurang 14 hari. Pasien Dalam Pengawasan (PDP) yaitu orang yang mempunyai gejala berat sehingga membutuhkan pengawasan agar tidak mengalami pemburukan kondisi. Orang Tanpa Gejala (OTG) yaitu orang yang tidak memiliki gejala namun memiliki riwayat kontak erat dengan orang yang positif COVID-19 sehingga berisiko tertular COVID-19. Positif yaitu pasien yang terkonfirmasi terinfeksi COVID-19. Oleh karena itu, lama rawat pasien COVID-19 akan berbeda tiap pasien tergantung pada status masing-masing pasien tersebut.

(4) Komorbid

Komorbid adalah suatu kondisi dimana pasien memiliki penyakit bawaan yang diderita selain COVID-19 [9]. Pasien yang menderita penyakit kronis biasanya memiliki imunitas lebih rendah dibandingkan dengan orang yang tidak 
memiliki komorbid. Oleh karena itu, pasien yang disertai dengan komorbid akan rentan terpapar virus COVID-19 hingga berakibat fatal pada kematian [10] [18].

\subsection{Data Penelitian}

Data yang digunakan pada penelitian ini merupakan data sekunder berupa data pasien-pasien COVID-19 yang dirawat pada Rumah Sakit Umum Pusat M. Djamil dan Rumah Sakit Universitas Andalas Padang, Sumatera Barat sebanyak 688 pasien selama bulan Maret - Juli 2020. Variabel tak bebas yang digunakan pada data ini adalah lama rawat inap pasien COVID-19 $(Y)$, sedangkan untuk variabel bebas yang digunakan adalah Usia $\left(X_{1}\right)$, Jenis Kelamin $\left(X_{2}\right)$, Diagnosa Pasien COVID$19\left(X_{3}\right)$, dan Komorbid $\left(X_{4}\right)$. Untuk variabel bebas $\left(X_{2}\right)$ dan $\left(X_{3}\right)$ merupakan variabel dummy dengan penjelasannya dapat dilihat pada Tabel 1 berikut.

Tabel 1. Variabel dummy untuk Jenis Kelamin dan Diagnosa pasien COVID-1

\begin{tabular}{|l|c|l|c|c|c|}
\hline \multicolumn{2}{|c|}{ Jenis Kelamin } & \multicolumn{4}{c|}{ Diagnosa Pasien COVID-19 } \\
\hline & $X_{2 D 1}$ & & $X_{3 D 1}$ & $X_{3 D 2}$ & $X_{3 D 3}$ \\
\hline Laki-laki & 1 & ODP & 1 & 0 & 0 \\
\hline Perempuan & 0 & PDP & 0 & 1 & 0 \\
\hline & & Positif & 0 & 0 & 1 \\
\hline & & OTG & 0 & 0 & 0 \\
\hline
\end{tabular}

\section{Hasil dan Pembahasan}

Pada tahap ini akan dilakukan estimasi pendugaan parameter model regresi kuantil Bayesian terhadap data lama rawat inap pasien COVID-19. Metode regresi kuantil Bayesian menggunakan MCMC dengan bantuan algoritma Gibbs sampling untuk mengestimasi distribusi posteriornya dengan software $R$ yang dilakukan pada data sebanyak 20.000 iterasi. Hasil estimasi pendugaan parameter model menggunakan metode regresi kuantil Bayesian disajikan pada Tabel 2 berikut.

Tabel 2. Hasil Estimasi Parameter menggunakan Metode Regresi Kuantil Bayesian

\begin{tabular}{|c|c|c|c|}
\hline \multirow{2}{*}{ Parameter Model } & \multicolumn{3}{|c|}{ Kuantil ke- } \\
\hline & 0,25 & 0,5 & 0,75 \\
\hline Usia $\left(X_{1}\right)$ & $-0,01435^{*}$ & $-0,00638$ & $-0,01174$ \\
\hline $\operatorname{ODP}\left(X_{3 D 1}\right)$ & $-0,32822$ & $-1,17508$ & $-1,50034$ \\
\hline $\operatorname{PDP}\left(X_{3 D 2}\right)$ & 0,96969 & 0,00796 & $-2,52119$ \\
\hline Positif $\left(X_{3 D 3}\right)$ & 3,80104 & $5,78899^{*}$ & 8,29400 \\
\hline Komorbid $\left(X_{4}\right)$ & $-0,22561 *$ & $-0,17221^{*}$ & $-0,17764^{*}$ \\
\hline
\end{tabular}

*Signifikan pada taraf nyata $\alpha=0,05$ 
Pada Tabel 2 dapat diketahui bahwa pada kuantil 0,25 variabel bebas Usia signifikan pada taraf nyata $\alpha=0,05$ dalam mempengaruhi lama rawat inap pasien COVID-19. Selanjutnya pada kuantil 0,5 variabel bebas dengan diagnosa pasien Positif signifikan pada taraf nyata $\alpha=0,05$ dalam mempengaruhi lama rawat inap pasien COVID-19. Selanjutnya tidak ada variabel bebas lain yang signifikan dalam mempengaruhi lama rawat pasien COVID-19 untuk tiap kuantil yang dipilih selain variabel Usia, Positif, dan Komorbid.

Setelah memperoleh nilai estimasi parameter pada regresi kuantil Bayesian, maka perlu diuji seberapa tepat model yang dihasilkan dengan menghitung nilai pseudo $R^{2}$. Berikut disajikan hasil perhitungan nilai pseudo $R^{2}$ pada Tabel 3 berikut.

Tabel 3. Nilai pseudo $R^{2}$ untuk Metode Regresi Kuantil Bayesian

\begin{tabular}{|l|c|}
\hline Kuantil ke- & pseudoR $^{2}$ \\
\hline 0,25 & 0,7014 \\
\hline 0,5 & 0,9613 \\
\hline 0,75 & 0,9823 \\
\hline
\end{tabular}

Pada Tabel 3 dapat dilihat bahwa kuantil 0,75 menghasilkan nilai pseudo $R^{2}$ tertinggi, maka model pada kuantil 0,75 merupakan model terbaik dalam melakukan pendugaan parameter dengan metode regresi kuantil Bayesian. Dengan demikian, model dugaan untuk estimasi parameter model regresi kuantil Bayesian kuantil 0,75 adalah sebagai berikut:

$$
\widehat{y}=-0,17764 X_{4}
$$

Setelah hasil estimasi parameter model regresi kuantil Bayesian diperoleh, analisis dilanjutkan dengan melakukan uji kekonvergenan parameter model. Untuk menguji kekonvergenan parameter dapat dilihat menggunakan trace plot, dan density plot. Berikut disajikan bentuk hasil uji kekonvergenan pada model untuk kuantil 0,75 yang disajikan pada Gambar 1 berikut ini.
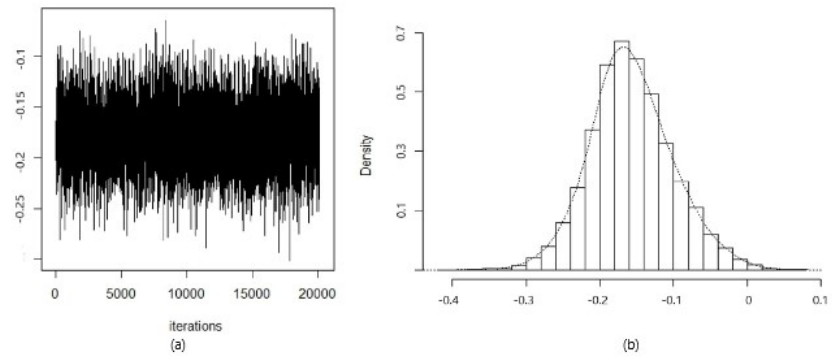

Gambar 1. Trace plot Variabel Komorbid Pada Kuantil 0,75. 
Berdasarkan Gambar (a) dapat dilihat bahwa nilai dugaan parameter Komorbid telah membentuk pola yang konvergen ke suatu nilai karena plot dari data sudah terletak diantara dua garis linier yang horizontal sehingga parameter model dikatakan telah konvergen. Gambar (b) dapat dilihat bahwa density plot untuk parameter Komorbid telah membentuk kurva yang menyerupai sebaran normal dan dapat dikatakan bahwa sebaran data iterasi yang dihasilkan berdistribusi Normal. Dengan demikian, diperoleh bahwa nilai dugaan untuk parameter Komorbid telah memenuhi kriteria kekonvergenan sehingga estimasi yang diperoleh dapat diterima.

\section{Kesimpulan}

Dalam kajian ini telah dilakukan estimasi parameter model menggunakan metode regresi kuantil Bayesian pada data lama rawat inap pasien COVID-19. Berdasarkan hal tersebut diperoleh bahwa variabel bebas yang mempengaruhi data lama rawat inap pasien COVID-19 yaitu Usia $\left(X_{1}\right)$, Diagnosa Pasien $\left(X_{3}\right)$, dan Komorbid $\left(X_{4}\right)$. Kuantil terbaik pada estimasi parameter model regresi kuantil Bayesian yaitu kuantil 0,75 yang diperoleh berdasarkan perhitungan nilai pseudo $R^{2}$ tertinggi dengan bentuk model dugaannya adalah sebagai berikut:

$$
\widehat{y}=-0,17764 X_{4}
$$

\section{Ucapan Terima kasih}

Penulis mengucapkan kepada Ibu Lyra Yulianti, Bapak Admi Nazra, dan Ibu Maiyastri yang telah memberikan saran dan masukan sehingga makalah ini diselesaikan dengan baik.

\section{Daftar Pustaka}

[1] Adams, S. H. dkk. 2020. Medical Vulnerability of Young Adults to Severe COVID-19 - Data from The National Health Interview Survey. Journal of Adolescent Health, $67: 362-368$.

[2] Alhamzawi, R., dan Yu, K. 2012. Variable selection in quantile regression via Gibbs Sampling. Journal of Applied Statistics, 39(4), 799 - 813.

[3] Bain, L.J. dan Engelhardt, M. 1992. Introduction to Probability and Mathematical Statistics. Second Edition. Duxburry Press, California.

[4] Box, G.E.P. dan Tiao, G.C. 1973. Bayesian Inference in Statistical Analysis. Addision Wesley Company. Inc: Philippines.

[5] Davino, C., Furno, M. dan Vistocco, D. 2014. Quantile Regression Theory and Applications. John Wiley dan Sons, Ltd.

[6] Delviyanti, O., Yanuar, F., dan Devianto, D. 2018. Simulation Study of the Implementation of Quantile Bootstrap Method on Autocorrelated Error. Cauchy - Jurnal Matematika Murni Dan Aplikasi, 5(3) : 95 - 101.

[7] Efron, B., dan Tibshirani, J. R. 1993. An Introduction to the Bootstrap. New York: Champman and Hall, Inc.

[8] Feng, Y., Chen, Y., dan He, X. 2015. Bayesian Quantile Regression With Approximate Likelihood. Bernoulli. 21(2) : 832 - 850 . 
[9] Gunawan, A., Prahasanti, K., Utama, M. R., dkk. 2020. Pengaruh Komorbid Hipertensi Terhadap Severitas Pasien Coronavirus Disease 2019. Jurnal Implementa Husada. 1(2) : 136 - 151.

[10] Keputusan Menteri Kesehatan Republik Indonesia Nomor HK.01.07/MENKES/413/2020 tentang Pedoman Pencegahan dan Pengendalian Corona Virus Disease 2019 (COVID-19).

[11] Kozumi H, Kobayashi G. 2011. Gibbs Sampling Methods for Bayesian Quantile Regression. Journal of Statistical Computation and Simulation. 81(11) : 1565 1578 .

[12] Ntzoufras, I. 1973. Bayessian Modelling Using WinBugs. Greece: A John Wiley and Sons, Inc.

[13] Rees E. M., dkk. 2020. COVID-19 Length of Hospitl Stay: A Systematic Review and Data Synthesis. BMC Medicine. 18(270).

[14] Sari, A. R., Rahman F., Wulandari A., dkk. 2020. Perilaku Pencegahan Covid19 Ditinjau dari Karakteristik Individu dan Sikap Masyarakat. Jurnal Penelitian dan Pengembangan Kesehatan Masyarakat Indonesia. 32 - 37.

[15] Satuan Pusat Penanganan 2020. "Peta Sebaran". https://covid19.go.id/peta-sebaran. Diakses pada 4 Januari 2021.

[16] Walpole, E.R. 1986. Pengantar Statistika. Edisi Ketiga. PT. Gramedia Pustaka Utama, Jakarta.

[17] World Health Organization. 2020. "Coronavirus". www.who.int. Diakses pada 10 Maret 2021.

[18] Xia W., Shao J., Guo Y., dkk. 2020. Clinical and CT Features In Pediatric Patients With COVID-19 Infection: Different Points From Adults. Pediatric Pulmonology. $1-6$.

[19] Yanuar, F., Yozza, H., dan Zetra, A. 2019. Bayesian Quantile Regression Methods in Handling Non-normal and Heterogeneous Error Term. Asian Journal of Scientific Research, 12(3) : $346-351$.

[20] Yu, K., dan Moyeed, R. A. 2001. Bayesian Quantile Regression. Statistics dan Probability Letters. 54 : $437-447$.

[21] Zhai, P., dkk. 2020. The Epidemiology, Diagnosis, and Treatment of COVID19. Elsevier B. V. and International Society of Chemotherapy. 